Nama : Putri Anatysia C

NRP : 130217205

$\mathrm{KP}: \mathrm{B}$

\title{
The Impact of Minister of Marine Affairs and Fisheries Regulation Number 12 of 2020 on the Sustainability of Lobster in Indonesia
}

Tayibnapis, A.Z., Wuryaningsih, L.E., \& Gora, R. (2020). The Impact of Minister of Marine Affairs and Fisheries Regulation Number 12 of 2020 on the Sustainability of Lobster in Indonesia. International Journal of Multicultural and Multireligious Understanding, 7(9), 130-136

Indonesia is a maritime country in terms of economic life Many people work as fishermen because of the potential for fisheries high due to the confluence of ocean currents. Indonesia which is an archipelago country which has special marine resources and has always been the target of fishermen from various countries that are equipped with modern and successful tools capture with a large number of scales. With the fisherman playing the host there are still a number of restrictions related to fisheries. Ministry of Maritime Affairs and fisheries seeks to find solutions in the field of fishing with replace environmentally friendly equipment. Revised government policies that create debate among stakeholders of interest is the policy of the Minister of Marine Affairs and Fisheries Number 12 of 2020 about Lobster and Crab Management in Indonesian Territory. And also policy Another minister that also needs to be revised is the legalization of fishing gears such as prawn trawlers, payang and cocktails which had previously been banned and is used, because the catching device is causing anxiety. The price of lobsters and lobster seeds is determined by the development of demand and offers both inside and outside the country. Increased demand in the market International encourages the issuance of new regulations, namely welfare fishermen / cultivators. But with these regulations often releasing the 
sustainability of lobster in Indonesia. With that, the Roma group invites all interested parties to be careful and careful in thinking ahead. Minister of Marine Affairs and Fisheries Regulation number 12 of 2020 disclose that the exporter is obliged to carry out lobster cultivation activities inside the country with regard to the community or local cultivators. And exporters are successful cultivating lobsters. Currently there are 30 companies that have received recommendation for exporting lobster seeds. Namely, PT. Samudera Bahari Sukses, PT Grahafoods Indo Pasifik and PT. Tania Asia Marina with the new regulations obliging exporters to release $2 \%$ of their harvest from the cultivation. In 2020, the production value of cultured lobsters is targeted to be 303 billion rupiah, and increase to 1.73 trillion rupiah in 2024. Next, cultivation lobster will be developed with several strategies, including development upstream-downstream supply chain system. Indonesian lobster exports are mostly focused on China, Taiwan, and Hong Kong Singapore. Several factors cause Indonesian lobster exports to be unable competing in international markets is a logistical problem, lack of market share, and the difficulty of obtaining lobster seeds for cultivation or rearing. To in the future, fisheries export requirements will be increasingly stringent in the international market, between otherwise there must be certainty that the lobsters produced do not come from fishing practices illegal and fraudulent fish. In this regard, Indonesia has implement certification of fish catches, Strategic steps for the management and trade of lobster in carrying out conservation What the central government can do is delay implementation of new policies, simplification of central and regional licensing, stop the export of lobster seeds, reduce the risk of death of marine mammals, up to choosing a more environmentally friendly lobster. fishing tools, as well as pattern setting partnerships so that there is legal certainty for cultivators and fishermen. The enforcement of the Minister of Marine Affairs and Fisheries Regulation Number 12 Year 2020 is proven to have a negative impact on the sustainability of lobsters in Indonesia. Regulations it favors investors more than fishermen / lobster cultivators and causing scarcity of lobster seeds, thus complicating the position of the cultivator. The new policy should not be implemented immediately without regard to capability fishermen and cultivators 
considering the many problems they are facing especially related to licensing which is very burdensome for cultivators. There are even indications partnerships are only used by companies to fulfill seed export requirements lobsters and cultivators are only used as tools and complements for get a lobster seed export license. 